\title{
ÆUSGS
}

science for a changing world

Prepared in cooperation with the Bureau of Indian Affairs

\section{Whole Rock Geochemistry and Grain-Size Analyses from Sediment and Rock near Tuba City Open Dump, Tuba City, Arizona}

By Raymond H. Johnson, Valerie K. Stucker, Robert J. Horton, and James K. Otton



Open-File Report 2013-1118

U.S. Department of the Interior

U.S. Geological Survey 


\section{U.S. Department of the Interior \\ SALLY JEWELL, Secretary}

\section{U.S. Geological Survey \\ Suzette M. Kimball, Acting Director}

U.S. Geological Survey, Reston, Virginia: 2013

For more information on the USGS-the Federal source for science about the Earth,

its natural and living resources, natural hazards, and the environment-visit

http://www.usgs.gov or call 1-888-ASK-USGS

For an overview of USGS information products, including maps, imagery, and publications, visit $h$ ttp://www.usgs.gov/pubprod

To order this and other USGS information products, visit http://store.usgs.gov

Suggested citation:

Johnson, R.H., Stucker, V.K., Horton, R.J., and Otton, J.K., 2013, Whole rock geochemistry and grain-size analyses from sediment and rock near Tuba City Open Dump, Tuba City, Arizona: U.S. Geological Survey Open-File Report 2013-1118, 2 p., http://pubs.usgs.gov/of/2013/1118/.

Any use of trade, firm, or product names is for descriptive purposes only and does not imply endorsement by the U.S. Government.

Although this information product, for the most part, is in the public domain, it also may contain copyrighted materials as noted in the text. Permission to reproduce copyrighted items must be secured from the copyright owner. 


\section{Contents}



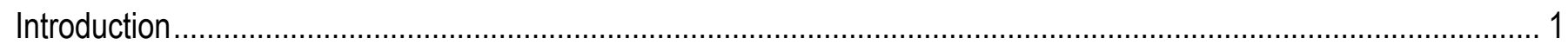

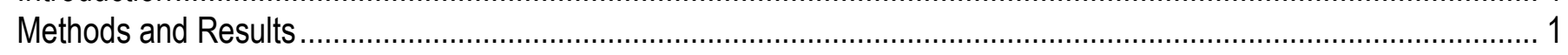

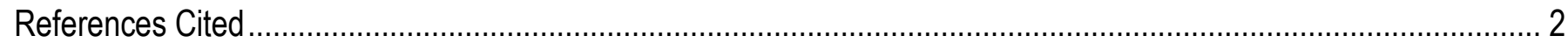

\section{Tables}

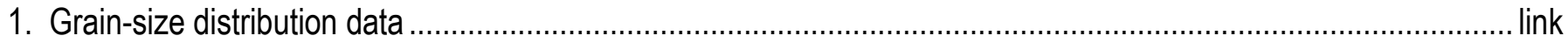

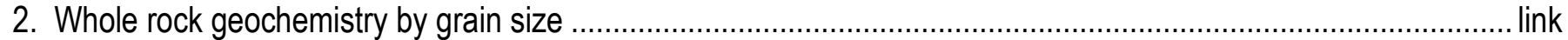

3. Duplicate whole rock geochemistry by grain size ............................................................................. link



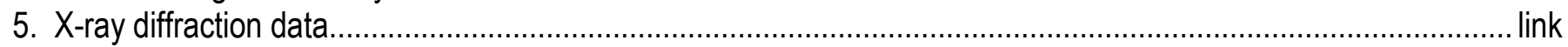




\title{
Whole Rock Geochemistry and Grain-Size Analyses from Sediment and Rock near Tuba City Open Dump, Tuba City, Arizona
}

\author{
By Raymond H. Johnson, Valerie K. Stucker, Robert J. Horton, and James K. Otton
}

\begin{abstract}
This report releases new information on grain-size distribution and whole rock geochemistry from samples collected in 2008 in and around Tuba City Open Dump, Tuba City, Arizona.

\section{Introduction}

A variety of sediment and rock samples were collected in and around Tuba City Open Dump in 2008. Whole rock geochemistry has already been reported for sediment/rock/dune samples in Johnson and others (2008). Many of these samples were sieved in order to get grain-size distributions. The resulting grain-size distributions along with new whole rock geochemistry associated with each grain-size category are provided in this follow-up report. In addition, whole rock geochemistry from cores collected at sites WP-03 and WP-14 and a few X-ray diffraction samples are provided. All sample locations and associated maps are provided in Johnson and others (2008).
\end{abstract}

\section{Methods and Results}

Grain-size analyses were completed using U.S. standard mesh-size sieves on an automatic shaker. Before sieving, aggregated material was broken up in a mortar and pestle as well as possible. The automatic shaker was run until no visible changes in sample size between the sieve sizes was apparent. The resulting data are provided in table 1 . Notes are provided in table 1 for coarser material that still appeared to be aggregates, generally of either clayey material or caliche.

Whole rock analyses on the sieved samples were completed by SGS laboratories in Toronto, Ontario, Canada, under contract with the U.S. Geological Survey (USGS) Minerals Program Laboratories in Denver, Colorado. These samples were prepared by air drying and grinding to less than 150 microns, if necessary (Taylor and Theodorakos, 2002), and then digested using multiple acids. The elemental concentrations in the digestion fluid were analyzed using a procedure similar to that of Briggs (2002) using inductively coupled plasma-atomic emission spectroscopy (ICPAES). The resulting data are provided in table 2. One additional sample (BH10TC001) is reported in table 2. This sample is calcareous cement separated from a conglomerate sample collected from the top of a mesa east of the Tuba City Open Dump site. This sample is matrix material only and all cobbles were removed. Sample BH10TC001 is not on the location maps in Johnson and others (2008), but latitude and longitude values are provided in table 2. In addition, splits from several samples (after drying and grinding) were also submitted to the USGS Minerals Program 
Laboratories in Denver, Colorado, for analyses using inductively coupled plasma-mass spectroscopy (ICP-MS) following the procedure described by Briggs and Meier (2002). Results from this limited suite of samples are provided in table 3.

Cores from locations WP-03 and WP-14 were collected using a hollow-stem auger rig. Coring and subsequent monitoring well installations were completed by a contractor for the Bureau of Indian Affairs. Grab samples from the cores were collected by the USGS and submitted for whole rock analyses with ICP-MS. The method for these analyses is the same as described above. Results from these analyses are provided in table 4.

Mineral phases were identified using X-ray diffraction analysis with Material Data, Inc. (MDI) Jade (version 9.1) search-match software from the International Centre for Diffraction Data's "2009 PDF-4" and National Institute of Standards and Technology and Fachinformationszentrum Karlsruhe cooperatively developed Inorganic Crystal Structure Database. Semiquantitative mineral estimates were calculated using MDI Whole Pattern Fit software, which simultaneously calculates a whole pattern fit and a Rietveld refinement of the minerals. Reference minerals are selected from the database, some of which are "structure" references that represent perfect crystals of the mineral, and other entries are more typical mineral specimens. Each reference contains a full crystallographic description of the mineral. A calculated model of the observed pattern is produced by nonlinear, least-squares optimization. The calculations, performed by the software, involve the application of various parameters to improve the fit of the model to the observed data. Modeling parameters include background reduction, profile fitting, and lattice constants. The software iterates and minimizes a residual error between the calculated X-ray diffraction patterns from the selected references in comparison to the measured scan of the sample. All data were normalized to 100 percent based on the identified minerals within a 1-percent error. A full description of the Whole Pattern Fit algorithm is available from MDI (William Benzel, USGS, written commun., 2011). Results from these analyses are provided in table 5.

\section{References Cited}

Briggs, P.H., 2002, The determination of forty elements in geological and botanical samples by inductively coupled plasma-atomic emission spectrometry, in Taggart, J.E., ed., chap. G, Analytical methods for chemical analysis of geologic and other materials, U.S. Geological Survey: U.S. Geological Survey Open-File Report 02-223-G, 18 p., http://pubs.usgs.gov/of/2002/ofr-02-0223/G01 fortyelementICP-AESsolid_M.pdf.

Briggs, P.H., and Meier, A.L., 2002, The determination of forty-two elements in geological materials by inductively coupled plasma-mass spectrometry, in Taggart, J.E., ed., chap. I, Analytical methods for chemical analysis of geologic and other materials, U.S. Geological Survey: U.S. Geological Survey Open-File Report 02-223-I, 14 p., http://pubs.usgs.gov/of/2002/ofr-02-0223/I20NAWQAPlus_M.pdf.

Johnson, R.H., Otton, J.K., Horton, R.J., Gallegos, T.J., Choate, L.M., and Sullivan, J.E., 2008, Geochemical data from analyses of rock, sediment, water, and solid-phase leaching at the Tuba City Open Dump, Tuba City, Arizona: U.S. Geological Survey Open-File Report 2008-1374, 10 p., http://pubs.usgs.gov/of/2008/1374.

Taylor, C.D., and Theodorakos, P.M., 2002, Rock sample preparation, in Taggart, J.E., ed., chap. A1, Analytical methods for chemical analysis of geologic and other materials, U.S. Geological Survey: U.S. Geological Survey Open-File Report 02-223-A1, 5 p., http://pubs.usgs.gov/of/2002/ofr-02-0223/A1RxSampPrep_M.pdf. 